\title{
Editorial policies on local authorship in rural health
}

\author{
Políticas editoriais sobre autoria local na saúde rural
}

Políticas editoriales sobre autoría local en salud rural

\author{
Leonardo Vieira Targa ${ }^{1,2}$, Mayara Floss ${ }^{3,4}$ \\ ${ }^{1}$ Universidade de Caxias do Sul (UCS), Caxias do Sul - RS, Brasil. \\ ${ }^{2}$ Sociedade Brasileira de Medicina de Família e Comunidade. Grupo de Trabalho em Saúde Rural \\ ${ }^{3}$ Working Party on the Environment da World Organization of Family Doctors (WONCA) \\ ${ }^{4}$ Grupo Hospitalar Conceição (GHC). Porto Alegre, RS, Brasil.
}

\begin{abstract}
Introduction: Community engagement in health research potentially benefits researchers, institutions and local people. Objective: This work reviews health journal policies looking for local authorship instructions, and clear specific recommendations on ethic issues for rural, remote or communities from low and middle income countries research publications. Methods: A research at National Library of Medicine, CAPES and Embase identified 37 journals related to rural health. A review of all instructions to authors were conducted independently by two authors, looking for any mention of local co-authorship or how to relate to local communities in the publication guidelines of the included journals. Results: Eleven [ $n=11$ ] journals fit the inclusion criteria and just one $[n=1]$ had any instruction or ethic concern about local authorship on the author's instructions. Most journals are from high income countries. Although the care in rural areas are more concentrated in Primary Care the journals were varied in its scope. Only four journals include in its description and scope primary care, general practice or family medicine. Conclusions: Authorship and publication policies should include specific and clear ethical recommendations related to community engagement in all major scientific communication vehicles. This should stimulate local participation through clear guidance to authors as a way of promoting a more inclusive, active and horizontal relationship between researchers and communities.
\end{abstract}

Keywords: Rural Areas; Rural Health; Authorship and Co-authorship in Scientific Publications.

\section{Resumo}

Introdução: O envolvimento da comunidade na pesquisa em saúde beneficia potencialmente pesquisadores, instituições e pessoas locais. Objetivo: Este trabalho analisa as políticas de periódicos de saúde em busca de instruções de autoria local e recomendações específicas claras sobre questões éticas para pesquisas em comunidades de áreas rurais ou remotas de países de baixa e média renda. Métodos: Uma pesquisa na Biblioteca Nacional de Medicina, CAPES e Embase identificou 37 periódicos relacionados à saúde rural. Uma revisão de todas as instruções aos autores foi conduzida de forma independente por dois autores, procurando qualquer menção à coautoria local ou como se relacionar com as comunidades locais nas diretrizes de publicação dos periódicos incluídos. Resultados: Onze [ $n=11]$ periódicos se enquadram nos critérios de inclusão e apenas um [n=1] teve alguma instrução ou preocupação ética com a autoria local nas instruções aos autores. A maioria dos periódicos é de países de alta renda. Embora os cuidados em saúde nas áreas rurais sejam mais concentrados na Atenção Primária, os periódicos foram variados em seu escopo. Apenas quatro revistas incluem em sua descrição e escopo cuidados primários, clínica geral ou medicina de família. Conclusões: As políticas de autoria e publicação deveriam incluir recomendações éticas específicas e claras relacionadas ao envolvimento da comunidade em todos os principais veículos de comunicação científica. Isso deve estimular a participação local por meio de orientações claras aos autores, como forma de promover um relacionamento mais inclusivo, ativo e horizontal entre pesquisadores e comunidades.

Palavras-chave: Áreas Rurais; Saúde Rural; Autoria e Coautoria em Publicações Científicas.

Como citar: Targa LV, Floss F.Editorial policies on local authorship in rural health. Rev Bras Med Fam Comunidade. 2020;15(42):2349. https://doi.org/10.5712/rbmfc15(42)2349

Corresponding author: Leonardo Vieira Targa E-mail: targalv@gmail.com Funding: none declared. Ethical approval: Does not apply Provenance: Not commissioned Peer review: External Received: 13/01/2020. Accepted: 12/05/2020. 


\section{Resumen}

Introducción: La participación de la comunidad en la investigación en salud potencialmente beneficia a investigadores, instituciones y personas locales. Objetivo: Este documento analiza las políticas de las revistas de salud en busca de instrucciones de autores locales y recomendaciones claras y específicas sobre cuestiones éticas para la investigación en comunidades en áreas rurales o remotas de países de ingresos bajos y medianos. Método: Una encuesta en la Biblioteca Nacional de Medicina, CAPES y Embase identificó 37 revistas relacionadas con la salud rural. Dos autores realizaron una revisión de todas las instrucciones para los autores de forma independiente, buscando cualquier mención de coautoría local o cómo relacionarse con las comunidades locales en las pautas de publicación de las revistas incluidas. Resultados: Once [ $n=11]$ revistas cumplieron con los criterios de inclusión y solo una [ $n=1]$ tuvo alguna instrucción o preocupación ética con la autoría local en las Instrucciones para los autores. La mayoría de las revistas son de países de altos ingresos. Si bien la atención médica en las zonas rurales está más concentrada en la atención primaria, el alcance de las revistas fue variado. Solo cuatro revistas incluyen atención primaria, medicina general o medicina familiar en su descripción y alcance. Conclusiones: Las políticas de autoría y publicación deberían incluir recomendaciones éticas específicas y claras relacionadas con la participación de la comunidad en todos los principales vehículos de comunicación científica. Esto debe alentar la participación local a través de directrices claras para los autores, como una forma de promover una relación más inclusiva, activa y horizontal entre investigadores y comunidades.

Palabras clave: Medio Rural; Salud Rural; Autoría y Coautoría en Publicaciones Científicas.

\section{INTRODUCTION}

Research in rural areas creates meaningful connections between researchers, institutions and local people. It generates good opportunities for local communities, smaller research centers and universities to learn and improve skills in contact to more experienced centers. It is also a great chance to those who are far and in another cultural context to learn and to get other insights related to this and future projects. Unfortunately, these partnerships are not as commonplace in the scientific world as they could be. In the literature, there are many studies of researchers from large centers without the concern of local involvement of the communities studied. In fact, most publications carried out in the least developed countries do not have co-authorship of local research institutes. ${ }^{1}$ There is an unjustifiable underrepresentation of co-authorship from low and middle income countries (LMIC) in research. ${ }^{1,2}$ Although international collaboration in research co-authorship is common, the number of partnerships decline according to the income level of the study country, even if the research is actually conducted in the LMIC. ${ }^{3}$

It is not today that we hear expressions like "Publish or Perish" in the academic world" and the amount of scientific output is often spurred on to the detriment of quality. One of the consequences of this pressure for scientific production can be seen in rural, remote and LMIC communities, which suffer from the so-called "research fatigue". ${ }^{4}$ This occurs for many reasons and in many ways but basically consists in the excess of local research (in length or repetitions), not always making clear to all participants about its means and objectives and not prioritizing locally applicable actions derived from outcomes or appropriate feedback.

In one study, using the terms health, rural and Brazil in January 2017, 1,611 publications were initially found in the Scientific Electronic Library Online (SciELO). ${ }^{5}$ After excluding no health related articles were identified 444 studies that assess the health of populations living in rural contexts or that analyze health policies directed at these scenarios. ${ }^{5}$ The recent and avid interest in rural research in the country, could be a sign of a paradigm shift and understanding of the specificity of rural health and the fruitful place for research.

Scientific journals can induce more ethically concerned practices through clear instructions to authors and a careful selection of what will be published. This work is a review of health periodic policies, looking for specific recommendations on ethic issues for rural, remote or underdeveloped communities. 


\section{METHODS}

A search was conducted from December 2017 to January 2018 using "rural" in the National Library of Medicine and using search fields filters for titles for "Journals referenced in the NCBI DBs", in the CAPES periodic research gate and on EMBASE Journal List. The criterion to determine whether the journal was health-related was the existence of the terms "health", "healthcare", "medical" or "disease" in their scope. A check was made regarding the activity of the journals through the links available from the PubMed record and through Google search tools. The authors repeated the research in April 2020 to update the results that remain equal to what was conducted in December 2017 to January 2018.

The inclusion criteria were: to be a scientific publication related to the health area and to be an active publication today. The activity criteria used was to have an active website at the moment of the search. Any periodic scientific publication presented in the databases above, was considered valid for the purpose of this research. The exclusion criteria: to be a newsletter or a government publication, to not have instructions for authors and not meeting the inclusion criteria.

A review of all instructions to authors were conducted by the two researchers independently, looking for any mention of local co-authorship or how to relate to local communities in the publication guidelines of the included journals. In case of divergence, there would be discussion between reviewers and a third evaluator could be invited. The data obtained from one or more journals would be cited and analyzed in the results and discussion of this work.

\section{RESULTS}

After the first appraisal, 37 of the initial 43 journals were selected because they were health related, these journals were analyzed more deeply. Fourteen had discontinued publication [ $n=14$ ] or are publications related to agribusiness, engineering and development [ $n=4]$; sociology [ $n=5]$; policy publications [n=1]; bulletins [ $n=2]$. The eleven journals selected had its policy analyzed (Figure 1). The focus in being a scientific publication in the health area was reinforced and respected by the blind evaluation between the authors. Figure 1 shows a flow diagram of the process of study selection.

A complete list of included journals links to their instructions to authors and the respective countries can be seen in Table 1.

\section{DISCUSSION}

It is interesting to note that from the eleven countries where the journals are based just one is a LMIC. Although the care in rural areas are more concentrated in Primary Care the journals were varied in its scope, the journals that include in its description and scope primary care, general practice or family medicine are only four: "Journal of Rural Medicine": JRM; "Rural and Remote Health"; "Semergen/Sociedad Española de Medicina Rural y Generalista”; "The Australian Journal of Rural Health".

It also had specialized publications like the "Online Journal of Rural Research \& Policy", which just accepts articles related to the Great Plains. Or more specialized in health fields like "Rural Mental Health Journal" and "Journal of Neurosciences in Rural Practice". In Latin America and Africa the primary care, family medicine and general practice do not have a specific local journal for publication. The "Indian Journal" is also more 


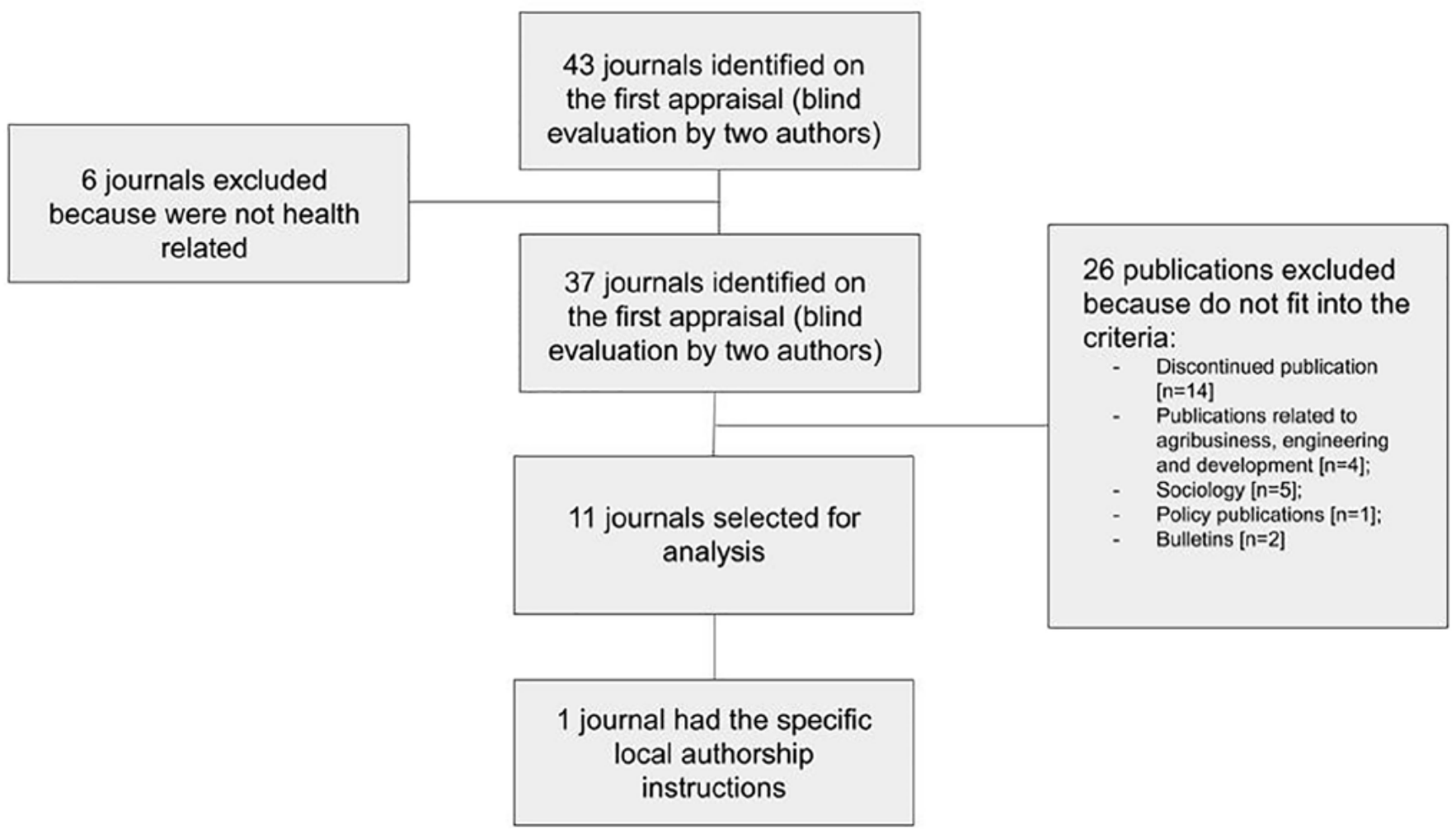

Figure 1. Flow diagram showing the process of study selection.

Table 1. Characteristics of the journals included in the review.

\begin{tabular}{|c|c|c|}
\hline Title & Authors instructions Journal Link & Country \\
\hline $\begin{array}{l}\text { Canadian Journal of Rural Medicine: the Official Journal } \\
\text { of the Society of Rural Physicians of Canada }\end{array}$ & https://srpc.ca/CJRM & Canada \\
\hline Journal of Neurosciences in Rural Practice & http://www.ruralneuropractice.com/author-instructions & India \\
\hline Journal of Rural and Community Development & $\begin{array}{l}\text { https://journals.brandonu.ca/jrcd/about/ } \\
\text { editorialPolicies\#focusAndScope }\end{array}$ & Canada \\
\hline Journal of Rural Medicine: JRM & https://www.j-rural-med.jp/about/about_jrm.html & Japan \\
\hline $\begin{array}{l}\text { Online Journal of Rural Nursing and Health Care: the } \\
\text { Official Journal of the Rural Nurse Organization }\end{array}$ & $\begin{array}{l}\text { https://rnojournal.binghamton.edu/index.php/RNO/about/ } \\
\text { submissions\#authorGuidelines }\end{array}$ & United States \\
\hline Online Journal of Rural Research and Policy & http://newprairiepress.org/ojrrp/ & United States \\
\hline Rural and Remote Health & https://www.rrh.org.au/journal/information_for_authors/ & Australia \\
\hline $\begin{array}{l}\text { Semergen/Sociedad Española de Medicina Rural y } \\
\text { Generalista }\end{array}$ & http://www.elsevier.es/ficheros/NormOrga/040normas.pdf & Spain \\
\hline The Australian Journal of Rural Health & $\begin{array}{c}\text { http://onlinelibrary.wiley.com/journal/10.1111/(ISSN)1440- } \\
\text { 1584/homepage/ForAuthors.html }\end{array}$ & Australia \\
\hline Rural Mental Health & http://www.apa.org/pubs/journals/rmh/?tab=4 & United States \\
\hline $\begin{array}{l}\text { The Journal of rural health: Official Journal of the } \\
\text { American Rural Health Association and the National } \\
\text { Rural Health Care Association }\end{array}$ & $\begin{array}{l}\text { http://onlinelibrary.wiley.com/journal/10.1111/(ISSN)1748- } \\
\text { 0361/homepage/ForAuthors.html }\end{array}$ & England \\
\hline
\end{tabular}


focused in neurosciences and not in primary care nor family medicine or general practice. This could also be related to the lack of research in continents out of high incomes countries and the lack of local authorship.

From the eleven [ $n=11]$ rural health journals that fit on the criteria just one $[n=1]$ had any instruction or ethic concern about local authorship on the author's instructions. "Rural and Remote Health" states that:

"For studies conducted in the developing world and for research into the Indigenous population of any country, there must be at least one local/Indigenous author. "Rural and Remote Health" aims to promote cross-cultural respect - and research should promote health by empowerment. In an era when Indigenous communities in many countries are using the phrase 'research fatigue', the presence of an author from the community of study hopefully indicates appropriate consultation, and culturally sensitive research that is at the least guided by the priorities of the community studied. No matter how enculturated the external researcher might be, subtle cultural barriers can impede the interpretation of data. The voice of the local community is clearest to those within that community, and an outsider's view is always that." 6

This very small number agrees with the literature in general ${ }^{1}$ and makes explicit how far we are from a scenario where the main vehicles induce ethic relationships between all involved in rural health research. Better results could be obtained if the relations between peripheral and central research centers would be stimulated to work together as we can see in many cases. ${ }^{7,8}$

The methodology used in this review has limited the search for medical journals found in the main Western databases and is limited to some languages, although relevant. In addition, although they are not explicitly included in the instructions to authors, it is possible for some editorial bodies of the journals studied to carry out some type of informal filter and ethical control regarding research in rural communities.

In order to stimulate the knowledge and investigative capacity of professionals and the health service, it is suggested to use participatory approaches with the rural population and not for it. ${ }^{5,9}$ To involve authors and local communities in its educational processes developed collectively and whose principles are the construction of new knowledge, the taking of joint decisions, awareness of the reality experienced, knowledge of the real and solid possibilities of finding solutions to common problems, the identification of priorities that will be objects of work and motivation for action. ${ }^{9}$ All of these are part of bringing the co-authorship to the editorial policies.

\section{CONCLUSIONS}

Although half the world's population lives in rural areas,${ }^{10}$ scientific production related to rural communities' health is markedly limited. When rural health research is done, special ethical concerns should exist in order to prevent dissociation between local and distant interests. Rural research is a great opportunity for all involved to learn and to share their specific skills and points of view, enriching the research process, results and satisfaction.

Editorial policies have a potential role inducing good practices. Specific authorship and publication policies should include ethical recommendations related to community or local engagement in all major scientific vehicles, especially those that publish research in rural and remote areas avoiding the "neocolonial science" in research. ${ }^{1}$ This should stimulate local participation through clear guidance to authors as a way of promoting a more inclusive, active and horizontal relationship between researchers and between researchers and communities. All involved in this process have potential benefits in establishing less asymmetric relations and exchanging experience and information. 


\section{AUTHORS' CONTRIBUTIONS}

Conception or design of the work: LVT and MF. Acquisition, analysis or interpretation of data: LVT and MF. Elaboration of the draft of the work and its critical review for important intellectual content: LVT and MF. Final approval of the version to be published: LVT and MF. The authors agree to be accountable for all aspects of the work, ensuring that issues related to the accuracy or integrity of any part of the work are properly investigated and resolved.

\section{REFERENCES}

1. Dahdouh-Guebas F, Ahimbisibwe J, Moll RV, Koedam N. Neo-colonial science by the most industrialised upon the least developed countries in peer-reviewed publishing. Scientometrics. 2003 Mar;56(3):329-43. DOI: https://doi.org/10.1023/A:1022374703178

2. Brandon AN. Publish or perish. Bull Med Libr Assoc. 1963 Jan;51(1):109-10.

3. Jacobsen KH. Patterns of co-authorship in international epidemiology. J Epidemiol Comm Health. 2009 Aug;63(8):665-9. DOI: https:// doi.org/10.1136/jech.2008.082883

4. Clark T.'We're Over-Researched Here!': exploring accounts of research fatigue within qualitative research engagements. Sociology. 2008 Oct;42(5):953-70. DOI: https://doi.org/10.1177/0038038508094573

5. Junqueira F, Cabral E, Ferreira F, Targa L, Almeida M, Rocha M et al. A pesquisa brasileira em contextos rurais: instrumento de justiça social. In: Savassi LCM, Almeida M, Floss M, Lima MC, ed. Saúde no caminho da roça. Rio de Janeiro: Editora FIOCRUZ; 2018. p. 97-110.

6. Rural and Remote Health. Information for Authors. Rural and Remote Health [Internet]. ANO; [access in ANO Mês dia]. Available from: https://www.rrh.org.au/journal/information_for_authors/\#ethics

7. Bierbaum M, Plueckhahn T, Roth F, McNamara C, Ramsey I, Corsini N. Challenges to uptake of cancer education resources by rural Aboriginal Health Workers: the Cancer Healing Messages flipchart experience. Rural Remote Health. 2017 Dec;17(4):4199. DOI: https:// doi.org/10.22605/RRH4199

8. Barcham R, Silas E, Irie J. Health promotion and empowerment in Henganofi District, Papua New Guinea. Rural Remote Health [Internet]. 2016 Oct/Dec; [cited ANO Mês dia]; 16(4):3553. Available from: www.rrh.org.au/journal/article/3553

9. Pinheiro S, Boef W. Pesquisas participativas "para" e "com" comunidades rurais: Caminhos diferentes para a construção socio-ambiental de conhecimentos agroecológicos. Rev Bras Agroecologia. 2007 Sep;2(2):398-401.

10. World Health Organization (WHO). Increasing access to health workers in remote and rural areas through improved retention: global policy recommendations. Geneva: WHO; 2010. 